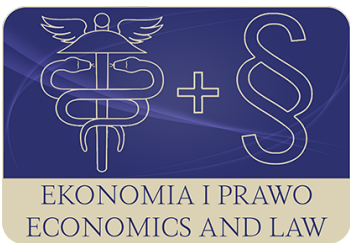

EKONOMIA I PRAWO. ECONOMICS AND LAW

Volume 17, Issue 1, March 2018

p-ISSN 1898-2255, e-ISSN 2392-1625

www.economicsandlaw.pl

EKONOMIA I PRAWO

ORIGINAL ARTICLE

received 13.06.2017; revised 01.12.2017; accepted 31.03.2018

Citation: Euczak, J. (2018). Police human resource policy in the Lodz voivodeship as a determinant of knowledge and organization's effective operation. Ekonomia i Prawo. Ecomomics and Law, 17(1):

71-82. doi:10.12775/EiP.2018.006.

\title{
Police human resource policy in the Lodz voivodeship as a determinant of knowledge and organization's effective operation
}

\author{
JOANNA EUCZAK \\ University of Social Sciences in Lodz, Faculty of Management, Department of Management, \\ ul. Sienkiewicza 9, 93-013 Łódź, Poland \\ 曰jluczak@spoleczna.pl
}

\begin{abstract}
Motivation: Human capital is the driving force of an organization that has a significant impact on its development and effective operation. The success of the organization depends to a great extent on its social potential. Successful recruitment ensures that the best employees ensure high quality work, which respectively translates into organizational development and competitiveness. The development of the organization is based on knowledge acquisition, skills and raising qualifications by its members.

Aim: The aim of the paper is to analyze the conditionings related to the management of the Police organizational units, which influence the appropriate recruitment of police officers for particular positions. The publication also attempts to investigate the importance of appropriate recruitment for the effectiveness of actions taken by police officers.

The article presents issues exemplifying the analysis of human resource management in the field of human resource policy playing an important role in the Police. The empirical part of the article was based on an analysis of the subject literature and police internal materials, but also on the basis of participant observation and expert interview. The paper presents an analysis of the recruitment process of police officers for vacant posts in the Police units of the Lodz garrison, introduced by the Human Resource Policy Concept.

Results: Although the Police was established to protect citizens' security and public order, its development and effective functioning are needed to further serve society. In order to do this, it is indispensable to recruit and employ proper and competent workers. There-
\end{abstract}


fore, the recruitment and selection process is so significant. Appointing a police officer with the right knowledge, competence and skills to a specific position, has positive implications for the organization. This also improves public perception of the Police force.

Keywords: public management; human resource management; police; recruitment; selection JEL: D73; D78

\section{Introduction}

All public organizations should make permanent changes to adapt to changing external conditions and maintain a high level of service delivery. When evaluating the functioning of public organizations, the quality of service as the fulfillment of social expectations should be taken into account. Polish police is undoubtedly a monopoly organization providing internal security services. Commercial companies are merely a complement to it. Despite this, the police have been improving their efforts to create a positive image among the citizens, as this has a significant impact on the confidence of the public (Euczak, 2013, p. 372).

The development of the organization is based on knowledge acquisition, skills and raising qualifications by its members. One can see how important the role of choosing the right candidate is and what the consequences are. Taking into account economic changes and the rapid development of civilization, there is, however, a need for a continuous analysis of the changing economic situation, which involves carrying out research aimed at showing current problems related to the essence of the above mentioned process.

Through gaining the right people, one can better stabilize, grow, and retain staff to achieve measurable results in the future. Although the Police was established to protect citizens' security and public order, its development and effective functioning are needed to further serve society. In order to do this, it is indispensable to recruit and employ proper and competent workers. Therefore, the recruitment and selection process is so significant.

\section{Methods}

The article presents issues which exemplify the analysis of human resource management in the field of human resource policy playing an important role in the Police. The purpose of the study is to analyze the determinants related to the management of the police organizational units, which affect the proper recruitment and selection of police officers for particular positions. The publication also attempts to investigate the importance of appropriate recruitment for the effectiveness of actions taken by police officers. The paper depicts an examination of the recruitment process of police officers for vacant posts in police units of the Lodz Voivodeship, introduced by the Human Resource Policy Concept. 
The analysis was empirical. Studies of the above problems meet the needs of acquiring skills to properly select candidates for a position in the Police in the Lodz garrison. Certainly, this is a problem that overwhelms all police units and their servants. A thorough scrutiny of the recruitment process in the Lodz Police was important as the conclusions of the research conducted could be implemented in other police organizational units in order to introduce good practices in the area of human resource management. Conducting up-todate explorations on recruitment process in a specific organization, that is Police, was essential to highlight the complexity of the problem. The investigations concerned both current issues of great importance for the police management staff and the officers performing the duties assigned to them.

The research methodology in this publication consisted in analyzing the contents of the subject literature and police internal materials. The conclusions could be also drawn on the basis of participant observation. The document analysis focused primarily on investigating the information contained in the Personnel Policy Concept for Police Officers in the Lodz garrison. Some legacies placed in the acts of law as regards the police organization were also used. These documents could include provisions on the conditions to be met in order for the recruitment and selection process to be carried out correctly and in accordance with all applicable and appropriate requirements.

At a later stage of the study expert interviews were conducted with people in the recruitment committee to deepen knowledge and supplement information on internal recruitment for the vacant post in police. Interviews conducted with those responsible for the recruitment process on the assessment of factors considered in the selection process have also allowed to gather detailed data. The information collected during the interviews made drawing conclusions possible.

The applied research program combines several research techniques as a set of conceptual and instrumental activities that cover the whole process of solving research problems. The methodology of the study was aimed at obtaining indepth data on selected aspects of the recruitment and selection process in yhe Police and its specificity. Owing to empirical research conducted, the issue of recruitment for vacant posts in the Police could be amplified.

\section{Human resource development in organizational progress}

Permanent technological advancement and civilizational changes present a challenge for new human activities. This necessitates the continuous replenishment of knowledge and the extension of existing competences, or the retraining or changing of occupation throughout professional life. Career development is an important component of the overall functioning of a human being. All off-work activities indirectly interweave with the professional sphere. Such penetration is helpful and enriches the competency of an employee. These are processes that run parallel, interpenetrate, and interact with one another. 
In a narrower context career development is defined as a process of broadening knowledge and developing skills and is used to create opportunities for deepening occupational interests and reinforcing capabilities. Continuous professional development at the individual and organizational level is vital from the worker's point of view in relation to the social relationship as well as to the overall development of the organization. The desirable state is when the needs of an individual overlap with the organization's objectives. However, the reality may appear different. Career development is defined as the process of creating opportunities for the development of occupational interests and employees' capabilities (Matthews et al., 2008, p. 168).

Over the years, as a result of organization's adjustment to changes, including public bodies, one can say that its workforce possessing specific competences are peculiar talents for the given organization or may affect its development (Hansen, 2007, pp. 12-13). Trust has been/ is acknowledged as a valuable managerial source within organizations. It fosters and increases voluntary compliance with organizational norms and rules, as well as enhances individual and organization's performance (Cho \& Poister, 2013, p. 816). Having the capability of creating distinctive skills (generating knowledge, creating and implementing innovations, providing appropriate organizational actions, responding to changes within the organization and its environment) means the ability to develop (Bileczyński, 2014, p. 261). The effectiveness of human resource policy is determined by the value of human capital measured by the suitability for an organization in the context of gaining competitive advantage or eliminating threats. An important thing is also human capital's uniqueness bearing in mind specific skills of individuals who have huge knowledge based on their own experience, skills, value system and intuition (Leptak \& Snell, 1999, pp. 31-48).

Qualitative changes aiming at improvement of organizational performance refer to its development that can be perceived as a process of upgrading the quality of human resources (Machado, 2016, p. 77). In the theory of human resource management, various concepts and theories of career development of an individual are discussed. The most important ideas comprise D. Levison's life structure theory, A. Roe's theory of career choice (a theory based on E. Schein's interests in which Roe identified and categorized a list of needs involving people's feelings concerning work), J. Hollan's theory — a hexagonal model based on individual personality development, or D. Super's Career Development Assessment and Counselling Model (C-DAC) which represents an excellent translation of career development theory into practice (Miś, 2007, pp. 84-97). According to J. Sutherland and D. Canwell (2007, pp. 181-182) the five basic functions of professional development include:

- expanding the knowledge base - helping to develop new information and conceptual understandings related to the changing goals and expectations of the business and the industry;

- learning from practice - learning from others how to put new concepts, ideas and models into practice; 
- developing new attitudes and beliefs - changing attitudes and beliefs are among the most difficult aspects of any profession. This means offering opportunities to exchange ideas with those who share similar realities, responsibilities and challenges/ problems and are willing to share strategies;

- opportunities for self-renewal - an individually oriented approach to professional development provides opportunities for employees' improvement at all levels;

- collaborating with and contributing to the growth of others - taking advantage of the expertise of others, and being recognized for one's own successes, can be an incentive for continued study and development.

The ability to manage an organization effectively and ethically is inseparably related to managerial competence, that is manager's proficiency and qualifications (Oleksyn, 2010, p. 21). Managers play an increasingly key role in organizational career development systems (Crawshaw \& Game, 2015, p. 1182). Management practice has helped to identify managers' models: courageous (identifying themselves with the organization, ambitious, driving at the future shape of the organization), defiant (wanting changes, that is those who put the blame on management's incompetence for the current state and strive for removing the 'wrongdoers'), unhappy (unambitious, dissatisfied with the way an organization functions, but they do not intend to take any actions), conformists (accepting the current situation in the organization, therefore they do not want any changes) (Hornstein, 1986, pp. 16-21). The change in the environment of nonprofit organizations has accentuated the need for managers to understand the relationship between strategy, HRM and organizational effectiveness (Akingbola, 2013, p. 479). Finding the right candidate for a vacancy is very important from an organizational point of view because a wrong decision will result not only in the choice of the wrong person, but will also heavily influence effective operation of the organization. Therefore, appropriate elaborating on recruitment, selection and staff appointment procedure in the organization is so essential (Kawka \& Listwan, 2002, pp. 78-80).

\section{Recruitment and selection as a process determining organization's effective operation}

Recruitment aims at attracting the most suitable people for the given position and therefore, it is an extremely important process in the human resource management system. Determining the right methods of recruiting candidates is significant for further recruitment and selection processes. Having known all virtues and drawbacks of the various methods and types of recruitment, employers can decide which method should be used. This choice depends on many factors; on the situation the organization is in, on the effort it intends to put in seeking appropriate candidates, on the hierarchical rung, or the funds the organization intends to allocate for this purpose. Such knowledge allows to better 
understand the essence and importance of the recruitment process and its impact on the overall functioning of the organization.

Recruitment methods can be divided into two groups. The external methods include: press releases, television and radio commercials, Internet, offices, employment and recruitment agencies, recommendations, schools, universities, and the organization's database. On the other hand, the internal methods of obtaining candidates for work comprise: reserve staff, advertisements, internal contests, list of successors, and internal recommendations. Internal recruitment procedure refers to the formerly recruited employees who are appointed to a different position within the same organization - it is so-called internal transfer. This method is applied while recruiting applicants. The result of the above described internal labor market is so-called the domino effect through the creation of another vacant post, after the employee leaves the previously occupied position. It is worth stressing that such a situation can have a positive impact on the development of human resources, as there is a great chance for employees to continue their further development.

Recruitment methods from internal sources have both advantages and disadvantages. It can be concluded that gaining candidates from the internal labor market is easier, cheaper, faster and less labor-consuming. This does not mean that it always happens, so when choosing the source of recruitment one has to consider other factors such as: labor market situation, domino effect, company development stage, organization's human resource management model, hierarchical rung and the importance of the given rank (Bieniok, 2006, p. 54). The advantages of the internal recruitment source include:

- low expenditure level;

- better knowledge of candidates for the given position;

- less risk of mistakes in appointment process;

- giving career opportunities for employees;

- greater motivation to work.

The drawbacks include:

- limited choice possibilities;

- employees' insufficient flexibility related to their readiness to perform new tasks;

- possible interference in interpersonal relationships (Pocztowski, 2007, p. 136).

The internal contest allows to select a group of ambitious people, which respectively motivates them to get involved in their tasks or encourages them to pursue self-development and improvement. While organizing an in-house contest it is crucial to appreciate employees who show ambition, a sense of initiative and bravery. The disadvantage of in-house competition may be that accessibility of better-educated and skilled workers from the external market is vastly constrained, furthermore, it may cause unfavorable connections between employees (Marek, 2008, p. 89). 
The recruitment process aims to find a group of people, among whom the best candidate for the given vacant post will be chosen. Each organization must fill labor shortages. Filling available vacancies, an organization should seek employees that are ready and able to satisfy their needs and meet their expectations. Therefore, it is necessary to analyze the usefulness of potential candidates. The essence of selection (selection) is choosing a new employee out of all candidates available. This action leads to the selection of an applicant with the skills and qualifications that meet all requirements specified in the requirements profile (Golnau et al., 2008, pp. 145-146). The essence of human resource selection is the adaptation of an individual to the type of work done, whereas the duties should be performed with minimum energy and maximum satisfaction with it. On the other hand, the aim of selection is to bring the characteristics of the given job and the employee's unique traits as close as possible. Selection is the key to success, because the proper selection of employees determines human capital which the organization will be equipped with, and what opportunities to develop and raise its efficiency it will have (Bieniok, 2006, p. 77). Choosing the selection method one should take into account not only a candidate's inclination to adapt to the current requirements of the post, but also their ability to conform to the anticipated direction those requirements might follow. In the context of frequent changes in the organizational environment, which entails employees' greater flexibility, this second type of adaptability can be particularly important for organizations.

\section{Vacancy appointment procedure in Police of the Lodz voivodeship}

In the Police actions, law-abidingness is of the greatest social importance. Nothing is so detrimental to the formation's authority as breaking the law by its representatives, even to the marginal extent. The effectiveness of actions that can contribute to the increased security within the society depends on the choices made by police officers. In order for the Police to come first among the institutions with the highest social trust, the main attention should be focused on the management in particular police units. Managerial staff should continually develop their skills and permanently strive for improving the management process of units and human resources in Police. In the light of constant changes and the need for permanent development of the organization, elaborating on a vacancy appointment procedure in police structures is absolutely indispensable. This procedure should contain the elements and criteria desired by superior to be performed by the police officer applying for the position. The above procedure is implemented in accordance with strictly defined stages, which are included in the Human Resource Policy Concept On Police Officers in the Lodz garrison. The policy came into effect in September 2016.

In compliance with the Human Resource Policy Concept, the recruitment process starts with formulating a vacant situation advertisement. It is the first 
and meaningful step which determines further selection process. Bearing in mind the appointment procedure, the manager of a given organizational unit should analyze all human resources in terms of internal transfer. All people taken into consideration, should be subjected to transparent and clear recruitment procedure. Each police officer ought to be notified of internal selection and when it starts. This stage is usually treated like an advertisement. If there are no suitable candidates or they are not selected, the manager should put forward a motion to their superior to announce internal selection in other organizational units. If the recruitment procedure collapses this time, the superior can search for the applicants in various units of the Lodz garrison, which a provincial police chief in Lodz should be notified of.

A situation vacant advertisement in a given unit is prepared by a human resource department. Police officers are informed about an available vacancy through websites, notice boards, officers' briefing, and official meetings. The advertisement should include:

- the name of a vacant post;

- qualifications required (in compliance with the Decree of Ministry of the Interior and Administration as of 19 June 2007 on requirements regarding education, vocational qualifications and service seniority, which should be met by police officers on managerial and other positions, and requirements on the appointment to high-ranking positions);

- desirable qualifications (in accordance with the job description form);

- education;

- service seniority and others (i.e. seniority in a given department);

- date and place of submitting a covering letter (in written form or via email, containing all data specified in the job advertisement).

The person announcing the selection appoints a committee conducting preliminary proceedings. The committee verifies candidates' qualifications in line with the above mentioned Decree and disciplinary punishability, on the basis of information gained from the Human Resource Department where an applicant remains in service. The candidates who do not meet requirements are rejected at this stage. The committee reports to the candidates' superiors who respectively publicize the results. In this process the effectiveness of tasks performed by the police officer and their impact on the performance of the whole organizational unit are vital. Vocational trainings or information about criminal, penal-administrative and disciplinary proceedings are also taken into account. On the basis of all information gathered, the committee draws up a ranking list. Afterwards, an applicant gets through an interview during which the following components are taken into consideration:

- self-presentation - dealing with stress, interpersonal abilities, faith in one's own abilities etc.;

- professional knowledge and availability;

- motivation. 
When the qualification procedure is completed, the committee creates a report in which they recommend an applicant for a vacant post. Having obtained a superior's approval, the manager of a given unit puts forward a personal motion or notifies the police officer of the necessity of reporting. In case it is necessary to transfer the police officer to a different police unit, the provincial police chief in Lodz is the person who makes a final decision. People that were positively verified during the qualification procedure belong to back-up staff for similar posts. Notification of the selection process completion regarding all details such as: a short job description, number of applicants, number of candidates positively graded, or if the procedure resulted in the selection of candidate or desisting from a procedure, and the score gained by the best candidate, is given to public in the same way as the internal vacancy advertisement.

The analysis of recruitment and selection process in police organizational units in the Lodz province allowed for in-depth examination of the issue. All information and recommendations are clearly defined in the Human Resource Policy Concept. Owing to this, recruitment and selection process is implemented thoughtfully and effectively. The whole process, starting with thorough planning of human capital needs, through job advertisement and final provisions, is carried out according to applicable regulations. People being in charge of the selection process always know a candidate's profile for a vacant post and get acquainted with a job description form. Selecting applicants they act in accordance with particular stages and precisely scrutinize each candidature. Awareness and knowledge of methods and techniques of gaining police officers for vacant posts facilitates selection of the proper candidate, neither wasting time not incurring unnecessary expenses related to the improper employee selection.

\section{Conclusion}

Employees' development is one of the most significant factors contributing to their satisfaction with work. It is treated like a kind of reward and gives an opportunity to further invest in one's skills and qualifications. Properly conducted recruitment and employee selection process certainly constitutes one of the key processes leading to the successful operation of the organization. Thanks to well-selected human capital all goals and tasks can be completed faster and more effectively. Badly-chosen batch of recruits may cause unnecessary delay in the work, seriously retard the organization's advancement and evoke conflicts or interference in the effective functioning of the whole organization. For those reasons hiring an appropriate arrival is an extremely important thing. Knowledge of people responsible for the recruitment and selection processes on the methods and techniques of gaining personnel and suitable preparation for these processes, that is familiarizing with job descriptions and potential candidates' profiles, might betoken selecting competent and skilled staff members. 
Protecting citizens against real dangers connected with the occurrence of military threats, technical breakdowns and natural calamities is one of the most critical tasks of each contemporary state. Skilful and dexterous functioning of public administration, particularly the Police (Nepelski, 2016, pp. 12-13), provides security and safety for citizens. A special challenge for police is management under huge social pressure. So as for the Police to perform their tasks in the proper manner, it has to be an institution open to the public, and at the same time its operation and actions ought to be effective. The necessity of improving unit and human resource management methods in the Police entails the compulsion to conduct research studies in this field. Detailed regulations referring to uniformed services cause the work in appropriate police units to be strictly adjusted to organizational structure and the vacancies offered. Proper human capital management allows to maximize police officers' capacity and makes their performance more effective, therefore, only a competent and skilled person should be appointed to a vacant post.

The mentioned and applied research instruments allowed to achieve the formerly defined research goal and investigate the research problem. Recruitment and selection process, which takes place in the Lodz Police, and various factors affecting the proper choice of a candidate were scrutinized. Owing to the research method, these processes could be depicted and illustrated from a practical point of view.

According to the study, one can conclude that managerial staff working in the Police are aware that the properly conducted selection process is crucial. This can be confirmed by the Provincial Police Headquarters in Lodz. The selection process here proceeds in compliance with all norms and requirements. It is strictly followed by the thoroughly planned schedule. Individuals belonging to the committee know the selection methods or techniques and familiarize with the previously prepared job description forms and candidates' profiles, which vastly facilitates the choice of a proper recruit. The binding Human Resource Policy Concept, in which the whole selection process is described, regarding people's responsibilities and tasks to be performed, greatly smoothes the path for skilful employee selection.

The issue covered in the publication certainly contributes to theory and practice. The analysis of research results shows that according to the management theory there are many factors meaningful to the human resource management. The conducted studies acknowledged the importance of proper employee selection as it vastly influences effective operation of the whole institution - the Police. The scrutinized example reveals that a thoughtful and thoroughly planned selection process enables the manager to hire a good employee, not exposing a police unit to any disturbances in its functioning. These studies can serve an introduction to further explorations of recruitment and selection process in police organizational units regarding the effectiveness of the Human Resource Policy implementation or application of this procedure in other voivodeships. The local influence of the investigation, that is on the territory of only one province, may 
cause some limitations and unnecessary generalization of conclusions (Stone \& Rosopa, 2017, p. 1). However, bearing in mind the organizational or hierarchical specificity of this institution and the same tasks police officers perform across the country, the results gained can be translated to other organizational units of Provincial Police Headquarters.

The Police implies more and more management tools and techniques. The superiors are aware that their actions should be based on management theory. The Police is a leading institution guaranteeing safety, law and order, therefore, a peculiar management style is applied here. In order to improve effectiveness and make this institution more professional, there are various changes implemented within the organization. Unit or human resource management is altered as well. These changes are deliberate and positively influence citizens' safety and protection (Euczak \& Troinska, 2016, p. 202) The discussed example unfolds that an attentively prepared and a thoughtfully planned selection process vastly facilitates police officers' occupational development, gaining knowledge or promotion. Thus, Police as an organization is subjected to continuous progression and development, and consequently completes tasks that civil servants are assigned to.

\section{References}

Akingbola, K. (2013). Contingency, fit and flexibility of HRM in nonprofit organizations. Employee Relations, 35(5). doi:10.1108/ER-01-2012-0009.

Bieniok, H. (2006). System zarządzania zasobami ludzkimi przedsiębiorstwa. Katowice: AE w Katowicach.

Bileczyński, J. (2014). Kategoria „zdolność rozwojowa organizacji” w zarządzaniu strategicznym. Marketing i Rynek, 2(5).

Cho, Y.J., \& Poister, T.H. (2013). Human resource management practices and trust in public organizations. Public Management Review, 15(6). doi:10.1080/ 14719037.2012.698854.

Crawshaw, J., \& Game, A. (2015). The role of line managers in employee career management: an attachment theory perspective. International Journal of $\mathrm{Hu}$ man Resource Management, 26(9). doi:10.1080/09585192.2014.934886.

Golnau, W., Kalinowski, M., \& Litwin J. (2008). Zarządzanie zasobami ludzkimi. Warszawa: CeDeWu.

Hansen, F. (2007). What's 'talent'?. Workforce Management, 86(1).

Hornstein, N.A. (1986). Managerial courage: Individual initiative and organizational innovation. Personel, 7.

Kawka, T., \& Listwan, T. (2002). Pozyskiwanie pracowników. In T. Listwan (Ed.), Zarządzanie kadrami. Warszawa: C.H. Beck.

Leptak, D.P., \& Snell, S.A. (1999). The human resources architecture. Towards of theory of human capital allocation and development. Academy of Management Review, 24(1). 
Łuczak, J. (2013). Polska Policja jako publiczna organizacja ucząca się. In B. Olszewska, M. Czarnecki, \& E. Piwoni-Krzeszowska (Eds.), Przedsiębiorstwo jako organizacja ucząca się. Wrocław: UE we Wrocławiu.

Łuczak, J., \& Stroińska, E. (2016). Specificity of reorganization in police based on the example of municipal police headquarters in Lodz. In R. Borowiecki, \& M. Dziura (Eds.), Dilemmas of restructuring of modern economy and enterprises. Theory - methods - practice. Kraków: UE w Krakowie.

Machado, C. (2016). Human resource management: an operational perspective, In C. Machado, \& J.P. Davim (Eds.). MBA. Theory And Application Of Business And Management Principles. Management and Industrial Engineering. Switzerland: Springer. doi:10.1007/978-3-319-28281-7.

Marek, J.(2008). Pozyskiwanie i dobór personelu. Ksztattowanie zatrudnienia w organizacji. Warszawa: Difin.

Matthews, J.J., Meggison D., \& Surtees M. (2008). Rozwój zasobów ludzkich. Gliwice: Helion.

Miś, A. (2007). Ksztattowanie karier w organizacji. Kraków: UE w Krakowie.

Nepelski, M. (2016). Zarządzanie w sytuacjach kryzysowych. Szczytno: WSPoL.

Oleksyn, T. (2010). Zarządzanie kompetencjami. Teoria i praktyka. Warszawa: Wolters Kluwer Business.

Pocztowski, A. (2007). Zarządzanie zasobami ludzkimi. Strategie - procesy metody. Warszawa: PWE.

Stone, D.L., \& Rosopa, P.J. (2017). The advantages and limitations of using meta-analysis in human resource management research. Human Resource Management Review, 27(1). doi:10.1016/j.hrmr.2016.09.001.

Sutherland, J., \& Canwell D. (2007). Klucz do zarządzania zasobami ludzkimi. Warszawa: PWN.

\section{Acknowledgements}

Author contributions: author has given an approval to the final version of the article.

Funding: this research was fully funded by the University of Social Sciences in Lodz, Faculty of Management, Department of Management statutory sources.

Note: the results of this study were presented at 9th International Conference on Applied Economics Contemporary Issues in Economy (June 22-23, Toruń, Poland). 